\title{
Importance of measles-specific intrathecal antibody synthesis index results in the diagnosis of subacute sclerosing panencephalitis
}

\section{Subakut Sklerozan Panensefalit tanısında kızamık spesifik intratekal antikor sentez indeksi sonuçlarının önemi}

\author{
Yasemin COSGUN ${ }^{1}$, Pervin OZELCi², Omur ALTINSOY', Gulay KORUKLUOĞLU1
}

\begin{abstract}
Objective: Subacute sclerosing panencephalitis (SSPE) is a serious disease that occurs after the measles virus is latent in the central nervous system (CNS), resulting in slow progression and death within 1-3 years. It is possible to reduce the incidence of the disease with routine measles vaccination during childhood. Analysis of cerebrospinal fluid (CSF) and serum samples taken simultaneously are used in the diagnosis of the disease as laboratory. In this study, it was aimed to evaluate the results of measlesspecific intrathecal antibody index of CSF and serum samples sent to our laboratory with SSPE pre-diagnosis.

Methods: In 2014-2015, 160 samples (80 CSF and 80 sera) of 80 patients with SSPE were collected simultaneously and sent to our laboratory. Measles immunoglobulin (IgG) levels in serum and CSF samples of patients were investigated in accordance with the manufacturer's recommendation with an indirect enzyme-linked immunosorbent assay (ELISA) kit (Measles Virus IgG ELISA for BOS Diagnostics, Euroimmun, Germany) which quantitatively detects specific antibodies in CSF. Total IgG and total albumin levels of serum and CSF samples with total IgG and albumin kits (BN Prospec, Siemens, Germany) with nephelometric method were determined as $\mathrm{mg} / \mathrm{L}$. The measles-specific
\end{abstract}

\section{ÖZET}

Amaç: Subakut Sklerozan Panensefalit (SSPE); kızamık virüsünün merkezi sinir sisteminde latent olarak kalması sonucu ortaya çıkan, yavaş ilerleyen ve 1-3 yıl içinde ölümle sonuçlanan ciddi bir hastalıktır. Çocukluk çağında yapılan rutin kızamık aşılaması ile hastalığın görülme sıklığını azaltmak mümkündür. Hastalığın laboratuvar tanısında eș zamanlı alınan beyin omurilik SIVısı (BOS) ve serum örneklerinde yapılan analizler kullanılmaktadır. Bu çalıșmada, SSPE ön tanısıyla laboratuvarımıza gönderilen BOS ve serum örneklerinin kızamık spesifik intratekal antikor indeksi sonuçlarının değerlendirilmesi amaçlanmıștır.

Yöntem: 2014-2015 yıllarında SSPE ön tanılı 80 hastaya ait 160 örnek ( 80 BOS ve 80 serum) eș zamanlı olarak alınarak laboratuvarımıza gönderilmiștir. Hastaların serum ve BOS örneklerinde kızamık immunglobulin G (lgG) düzeyi, kantitatif olarak BOS'ta özgül antikor saptayan indirekt enzim-linked immunosorbent assay (ELISA) kiti (Measles Virus IgG ELISA for BOS Diagnostics, Euroimmun, Almanya) ile üretici firmanın önerileri doğrultusunda araștırılmıștır. Ayrıca nefelometre cihazında (BN Prospec, Siemens, Germany) albümin ve total IgG kitleri (Albumin, IgG, Siemens, Germany) ile serum ve BOS örneklerinin

${ }^{1}$ Ministry of Health, Public Health General Directorate, National Virology Reference Laboratory, Ankara

${ }^{2}$ Ministry of Health, Public Health General Directorate, Vaccine Preventable Diseases Department, Ankara

İletişim / Corresponding Author : Yasemin COSGUN

DOI ID : 10.5505/TurkHijyen.2019.93764

Cosgun Y, Ozelci P, Altınsoy O, Korukluoglu G. Importance of measles-specific intrathecal antibody synthesis index results in the diagnosis of subacute sclerosing panencephalitis. Turk Hij Den Biyol Derg, 2019; 76(3): 335-340 
antibody index was calculated according to the results obtained from these tests. The obtained CSQrel (relative BOS / serum quotient) value of $\geq 1.50$ was considered to be indicative of intrathecal measles antibody production in the cases, equivocal range between $1.30-1.50$ and $\leq$ 1.30 as normal range.

Results: Fifty (62\%) male and 30 (38\%) female patients were analyzed in a total of 80 patients. Measles antibody synthesis index (ASI) value; 15 (18.75\%) of the 80 patients were found to be positive, $2(2.5 \%)$ intermediate value and 63 (78.75\%) negative. Nine (60\%) male and 6 (40\%) female patients with measles ASI values $\geq 1.50$ were detected in 15 patients. Their ages were between 8 and 21 and the median age was 16.6. The index values of these 15 patients were calculated between 1.94 and 107.75 .

Conclusion: SSPE should be considered and necessary tests should be performed in the differential diagnosis of encephalitis patients. Although clinical findings and EEG findings of the patient are important, identification of the presence of intrathecal antibody synthesis is an important criterion in the diagnosis of the disease. Early identification of the disease ensures protection from long-term, unnecessary and invasive treatments and enables receiving appropriate treatment.

Key Words: SSPE, measles, diagnosis total IgG ve total albümin düzeyleri $\mathrm{mg} / \mathrm{L}$ olarak saptanmıştır. Bu testlerden elde edilen sonuçlara göre kızamık spesifik antikor indeksi hesaplanmıștır. Elde edilen CSQrel (relative BOS/serum quotient) değerinin $\geq 1.50$ olması, olgularda intratekal kızamık antikor üretiminin göstergesi olarak kabul edilmiș, 1.30-1.50 arası aradeğer, $\leq 1.30$ ise negatif olarak değerlendirilmiștir.

Bulgular: Örnekleri analiz edilen toplam 80 hastanın 50 (\%62)'si erkek, 30 (\%38)'u kadındı. Kızamık ASI değeri; 80 hastanın $15(\% 18,75)$ 'inde pozitif, 2 $(\% 2,5)$ 'sinde aradeğer, $63(\% 78,75)$ 'ünde ise negatif olarak saptandı. ASI değeri; $\geq 1.50$ saptanan 15 hastanın 9 (\%60)'u erkek, 6 (\%40)'sı kadındı. Yașları 8 ile 21 arasındaydı ve yaș ortalaması 16.6 hesaplandı. Bu 15 hastanın indeks değerleri 1.94 ile 107.75 arasında hesaplandı.

Sonuç: Ensefalitli hastaların ayırıcı tanısında SSPE düşünülmeli ve gerekli testler yapılmalıdır. Tanıda hastaya ait klinik ve EEG bulguları önemli olmakla birlikte intratekal antikor sentezi varlığının gösterilmesi önemli bir kriterdir. Teșhisin erken konulması, hastanın uzun süreli, gereksiz ve invaziv tedavilerden korunmasını ve uygun tedavi almasını sağlamaktadır.

Anahtar Kelimeler: SSPE, kızamık, tanı

\section{INTRODUCTION}

SSPE is a serious disease that occurs due to latent measles virus in the CNS, slowly progressive, usually manifested by myoclonic seizures, and death in almost all patients within 1-3 years. Cases of measles are considered to have developed SSPE in 4-11/100.000, but it is known that in measles infections in the first years of life, the risk of developing SSPE is increased. The disease is seen on average seven years (1 month - 27 years) after measles infection $(1,2)$. It is possible to reduce the incidence of the disease with routine measles vaccination during childhood

(3). Most likely the measles virus reaches the CNS via the hematogenous transmission during the primary infection. Mutation in viruses, particularly proteins $M$ and $F$, leads to continued viral transcription and subcellular localization of the virus components. Since virus proteins can not be excreted from the host cell membrane, an appropriate immune response against the host cell can not be established. Inflammatory changes in the brainstem, the progression of the cellular and humoral immune system processes, which continue with the increase of various inflammatory 
mediators in the cerebrospinal fluid (CSF), result in destruction of the periventricular white matter and cortical area, and thus the clinical picture of the disease $(4,5)$.

The diagnosis of the disease is made when at least two of the following laboratory criteria exist in addition to the presence of clinical findings.

1. Characteristic electroencephalographic findings of SSPE,

2. The presence of typical histopathologic changes in brain autopsy or biopsy specimens,

3. Detection of high-level measles antibodies in the CSF,

4. Identification of measles virus RNA or antigen in brain tissues (6).

In late-onset slow virus infection, high antibody titers against measles virus were detected in patients serum and CSF (7) and measles virus was shown in brain tissue in patients with SSPE clinical findings (8). The increase in measles-specific lgG BOS / serum ratios was accepted as an important criterion in the diagnosis of SSPE. The BOS / serum concentration coefficient of the albumin was considered as the best indicator in defining the blood - CSF barrier dysfunction (9). In this study, we aimed to evaluate the results of measles-specific intrathecal IgG antibody index of CSF and serum samples sent to our laboratory by SSPE pre-diagnosis.

\section{MATERIAL and METHOD}

Between January 2014 and December 2015, 160 samples ( 80 CSF and 80 serum) of 80 suspected SSPE patients were taken simultaneously and sent to our laboratory. In the serum and CSF samples of patients, measles IgG levels were quantitatively investigated in the direction of the manufacturer's recommendation with an indirect ELISA kit (Measles Virus IgG ELISA for BOS Diagnostics, Euroimmun, Germany) that detected specific antibody in CSF and measles specific lgG levels were determined in units/mL (10). Total IgG and total albumin levels of serum and CSF samples were also measured in $\mathrm{mg} / \mathrm{L}$ with total albumin and total IgG kits (Albumin, IgG, Siemens, Germany) using a nephelometer (BN Prospec, Siemens, Germany) (11). The measles-specific intrathecal antibody synthesis index was calculated according to the Reiber formula using the obtained CSF-specific IgG, serum-specific IgG, CSF total IgG, serum total IgG, CSF albumin and serum albumin results (12). In the calculation, the formulated calculation table prepared by the manufacturer is used. The obtained CSQrel (relative BOS / serum quotient) value of $\geq 1.5$ was considered to be indicative of intrathecal measles antibody production in the cases, equivocal range between $1.30-1.50$ and $\leq 1.30$ as normal range. The results are also shown using the Reiber diagram to interpret the results clinically (Figure 1) $(12,13)$.

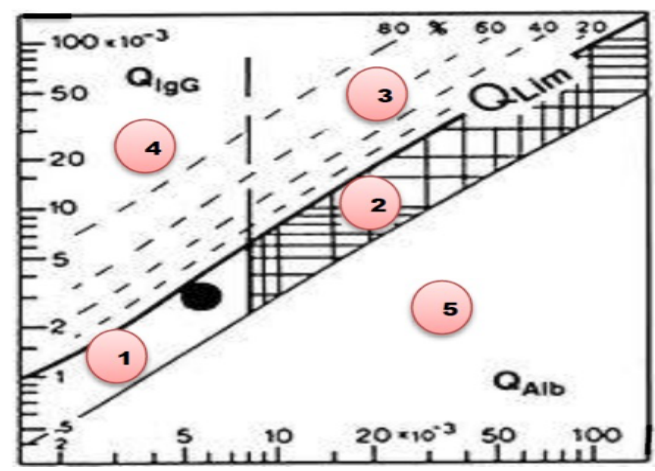

Figure 1. Diagram used to demonstrate the presence of intrathecal antibody synthesis. (1) Normal range; (2) Blood-CSF barrier disorder without local intrathecal antibody synthesis; (3) Localized intrathecal antibody synthesis in CNS with blood-CSF barrier disorder; (4) Presence of local intrathecal antibody synthesis without blood-CSF barrier disorder; (5) Methodological error (12,13) 


\section{RESULTS}

Of the 80 patients analyzed, $50(62 \%)$ were male and 30 (38\%) were female. Their ages ranged from 2 to 38 years, median age 12.25 was detected. Measles antibody synthesis index; 15 (19\%) of 80 patients were positive, 2 (3\%) were equivocal and 63 (79\%) were in the normal range. Of 15 patients with ASI $\geq 1.5,9(60 \%)$ were male and $6(40 \%)$ were female. They were between 8 and 21 years old and median age was 16.6 (Figure 2). The distribution of births of these patients by geographical area is given in Figure 3. Measles ASI values of these 15 patients were calculated between 1.94 and 107.75 . Eight (54\%) of 15 patients with high index scores were between 1.5 and $10.2(13 \%)$ were between 10 and 20 and 5 (33\%) were over 20 (Figure 4).

CSQrel: Intrathecal Pathogen Specific Antibody Production Index (CSQ spec lgG / CSQ total lgG)

CSQspec lgG: CSF agent specific IgG / Serum agent specific IgG

CSQtotal IgG: CSF total IgG / Serum total IgG

If CSQtotal IgG $\leq$ CSQlim: CSQrel = CSQpath.spec. IgG / CSQtotal IgG

If CSQtotal IgG $\geq$ CSQlim: CSQrel = CSQpath.spec. IgG / CSQlim

If CSQrel $\geq 1.5$, intrathecal antibody was synthesized due to a local infection in CNS.

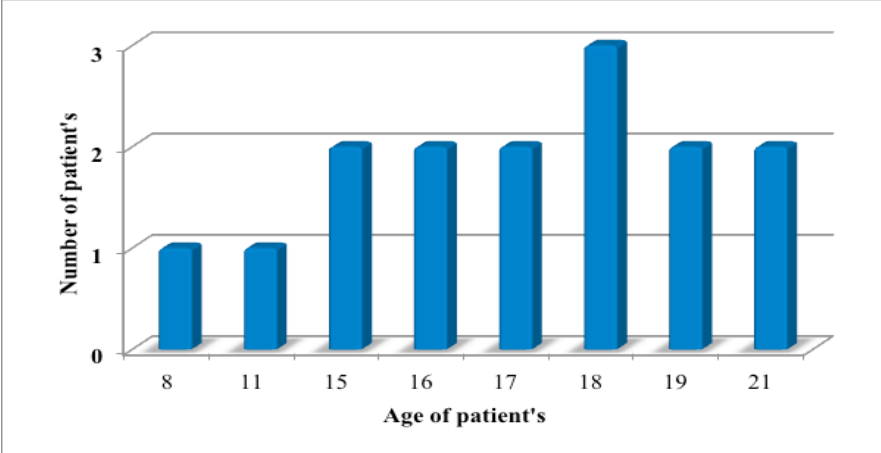

Figure 2. Age distribution of patients with positive results

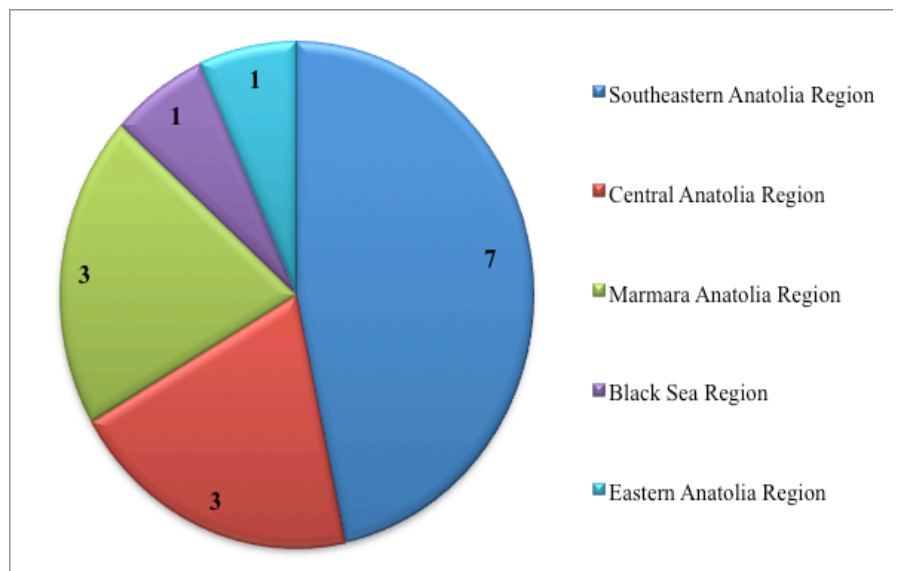

Figure 3. Distribution of positive patients by geographical regions 


\begin{tabular}{|c|c|c|c|c|c|c|c|c|c|c|c|c|c|c|c|}
\hline$\pi$ & 8 & $t$ & U & $E$ & 1 & 0 & H & 1 & j & $\pi$ & $T$ & $\pi$ & $\pi$ & प & P \\
\hline \multirow{2}{*}{ 10-number } & $\begin{array}{c}\text { serum } \\
\text { leg spec. }\end{array}$ & $\begin{array}{c}\text { serum } \\
\text { lpg spec. }\end{array}$ & $\begin{array}{c}\text { serum } \\
\text { log spec. }\end{array}$ & $\begin{array}{c}\text { CSF } \\
\text { lgo spec. }\end{array}$ & $\begin{array}{c}\text { CSF } \\
\text { lpo spec. }\end{array}$ & $\begin{array}{c}\text { CSF } \\
\text { log spec. }\end{array}$ & $\begin{array}{c}\text { serum } \\
\text { leg total }\end{array}$ & $\begin{array}{c}\text { CSF } \\
\text { lqg total }\end{array}$ & $\begin{array}{l}\text { serum } \\
\text { albumin }\end{array}$ & $\begin{array}{c}\text { CSF } \\
\text { albumin }\end{array}$ & CSQspec & CSQtotal & CsQalb & CsQlim & csQrel \\
\hline & units & Givisen- factor & calculated & units & dituboen-tactor & calculated & mgl & moll & mgli & mgl & $\times 10^{3}$ & $\times 10^{3}$ & $\times 10^{3}$ & $\times 10^{3}$ & \\
\hline 1) & 124,00 & 12856 & 1594079.72 & 154.94 & 1024 & 150857,54 & 1490000 & 146.00 & 46500,00 & 202,00 & 99.53 & 9.80 & 4.34 & 2.94 & 33,88 \\
\hline 2 & 204,91 & 25856 & 5298204,67 & 227,00 & 512 & 116224,00 & 9620,00 & 132.00 & 40900,00 & 203,00 & 21,94 & 13,72 & 4,96 & 3,45 & 6,36 \\
\hline 3 & 34,00 & 6404 & 219776,00 & 14,79 & 10 & 147,90 & 28000,00 & 5,02 & 24900,00 & 16,50 & 0,67 & 0,18 & 0.68 & 0,06 & 3,83 \\
\hline 4 & 49,10 & 413996 & 20313300.99 & 230,00 & 8192 & 1884160,00 & 17400,00 & 316,00 & 44400,00 & 93,50 & 92,75 & 18,16 & 211 & 1,30 & 71,12 \\
\hline 5 & 201,00 & 25856 & 519705600 & 280,00 & 512 & 14336000 & 2010000 & 184,00 & 36700.00 & 117,00 & 27,58 & 9.15 & 3,19 & 2.04 & 13,53 \\
\hline 6 & 37,93 & 206848 & 7844710,40 & 82,40 & 2048 & 168753,15 & 16900.00 & 88,50 & 41400,00 & 75,80 & 21,51 & 5.24 & 1.83 & 1,14 & 18,80 \\
\hline 7 & 412,97 & 404 & 106838,67 & 479,33 & 2 & 958,67 & 20700,00 & 282,00 & 56700,00 & 146,00 & 5,75 & 13,62 & 2,57 & 1,61 & 3,58 \\
\hline 8 & 362,37 & 404 & 146396.27 & 324.97 & 2 & 649,93 & 1460000 & 5260 & 44400,00 & 83,50 & 4,44 & 3,60 & 1,88 & 1,17 & 3,79 \\
\hline 9 & 93,53 & 25856 & 2418363,39 & 136,40 & 1024 & 139677,70 & 13000,00 & 65.80 & 44100,00 & 154,00 & 57,76 & 5,06 & 3,49 & 2.27 & 25,48 \\
\hline 10 & 42,31 & 25856 & 1093993,22 & 225,93 & 128 & 28918,53 & 11200,00 & 65,20 & 47800,00 & 260,00 & 26,43 & 5,82 & 5,44 & 3,85 & 6,87 \\
\hline 11 & 39,49 & 103424 & 4084317,18 & 113,88 & 8192 & 932864,00 & 10900,00 & 259,00 & 38600,00 & 147,00 & 228,40 & 23,78 & 3,81 & 2,51 & 90,96 \\
\hline 12 & 231,00 & 6464 & 1493184,00 & 230,00 & 64 & 14720,00 & 11100,00 & 92,30 & 41800,00 & 124,00 & 986 & 8,32 & 297 & 1,88 & 5,25 \\
\hline 13 & 196,93 & 1616 & 318238,60 & 129.23 & 512 & 66165,76 & 2900,00 & 39,50 & 26000,00 & 79,00 & 207,91 & 13,62 & 3,04 & 1,83 & 107,75 \\
\hline 14 & 18,57 & 404 & 7501,88 & 16,03 & 2 & 32,06 & 7130,00 & 23,00 & 41400,00 & 92,60 & 4,27 & 3,23 & 2.24 & 1,38 & 3,09 \\
\hline 15 & 71,50 & 404 & 28887,62 & 65,34 & 2 & 130,68 & 15300,00 & 35,60 & 38200,00 & 176,00 & 4,52 & 2,33 & 4,61 & 3,15 & 1,94 \\
\hline & & & 0,00 & & & 0,00 & & & & & \#SAYVDI & ASAYNOI & "HSAYVII & ISAYYOI & \#SAYVIO! \\
\hline
\end{tabular}

Figure 4. Calculation of the relative CSF serum-quotient (CSQrel) and ASI values of patient

\section{DISCUSSION}

SSPE is not a disease often thought by clinicians because of its unusual manifestations such as behavioral changes, decline in school achievement, hyperactivity, and it is rarity. However, when more prominent neurological findings such as speech and gait disturbances, tremor, myoclonic contractions, or choreiform involuntary movements come to the fore, it is considered to prediagnosis. EEG findings may be normal or may show nonspecific slowness in the early stage of the disease. Typical EEG findings are periodic high-amplitude, sharp, and slow waves associated with myoclonic contractions. Magnetic resonance (MR) imaging is normal throughout the early phase of the disease, but with progression of the disease, increased T2 signals may be seen in the cerebral white matter and brain stem (14). For all of these reasons, laboratory testing is the foreground. High ASI value; it is significant in terms of confirmating the clinical diagnosis and directing the treatment (15). Detection of measles virus protein or RNA in brain tissue also confirms the diagnosis of SSPE, but these are tests that can be performed on biopsy or autopsy material. It is known that the incidence of SSPE is higher in populations with lower vaccination rates and the incidence of SSPE is significantly reduced following measles vaccination (16). In some cases, there is no history of measles disease in childhood. This is explained by the fact that maternal antibodies can be protective in children up to 6 - 8 months and that measles disease can be subclinically (17). In our study, four out of fifteen cases with a CSQrel value of $\geq 1.5$ were able to reach the history of measles disease, none of the others could be reached. It is important that the CSF and blood sample be taken simultaneously from the patient and laboratory tests should be run simultaneously so that the index can be determined correctly. SSPE is reported mostly in boys, but the cause of this gender gap has not been explained (18). In our study, similarly, $60 \%$ of the patients with positive antibody synthesis index were male. The mean age of the illness was reported to be $12-13$ years in the literatüre $(19,20)$, whereas it was 16.6 in our study. In 4 cases with measles disease history, the age of illness is between 1 and 2 years of age. There was no link between the age of measles and the age of getting SSPE. 


\section{CONCLUSION}

SSPE is a public health problem that remains important in the world and in our country despite high vaccination rates. Clinical, EEG, and MR findings are important in the diagnosis of the disease, but laboratory tests are needed to confirm it, and detection of high measles IgG antibody rates in CSF is diagnostic. In the differential diagnosis of encephalitis patients, SSPE should be considered and necessary tests should be performed. The early identification of the patient ensures that the patient is protected from long-term, unnecessary, and invasive treatments and receives appropriate treatment.

\section{REFERENCES}

1. Weekly epidemiological record, 13 January 2006, 81th year, ANNÉE No. 2, 2006, 81, 13-20 World Health Organization, Geneva / Abonnement annuel Sw. fr. / Fr. s. 334.- 01.2006 ISSN 0049-8114.

2. Anlar B, Yalaz K. Prognosis in subacute sclerosing panencephalitis. Dev Med Child Neurol. 2011; 53 (10): 965.

3. Bellini WJ, Rota JS, Lowe LE, RS Katz, PR Dyken, SR Zaki, et al. Subacute sclerosing panencephalitis: more cases of this fatal disease are prevented by measles immunization than was previously recognized. J Infect Dis. 2005; 192 (10): 1686-93.

4. Anlar B, Söylemezoğlu F, Aysun S, Köse G, Belen $\mathrm{D}$, Yalaz $\mathrm{K}$, et al. Tissue inflammatory response in subacute sclerosing panencephalitis (SSPE). J Child Neurol. 2001; 16 (12): 895-900.

5. Anlar B, Saatci I, Kose G, Yalaz K. MRI findings in subacute sclerosing panencephalitis. Neurology.1996; 47 (5): 1278-83.

6. https://www.cdc.gov/vaccines/pubs/pinkbook/ meas.html\#complications (accessed 12 October 2018).

7. Connolly JH, Allen IV, Hurwitz LJ, Millar JH. Measlesvirus antibody and antigen in subacute sclerosing panencephalitis. Lancet. 1967; 1 (7489): 542-4.

8. Horta-Barbosa L, Fuccillo DA, Sever JL, Zeman W. Subacute sclerosing panencephalitis: isolation of measles virus from a brain biopsy. Nature. 1969; 221 (5184): 974.

9. Reiber H, Lange P. Quantification of virus-specific antibodies in cerebrospinal fluid and serum: sensitive and specific detection of antibody synthesis in brain. Clin Chem. 1991; 37 (7): 115360.

10. Euroimmun Medizinische Labordiagnostica AG. Antibody determination in BOS. http://www. euroimmun.de/products/techniken/mikrotiterelisa/elisa-beschreibung.html (accessed 18 October 2018)
11. BN Prospec, Siemens, Germany, https://www. healthcare.siemens.com.tr/plasma-protein / systems/bn-prospec-system (accessed 28 October 2018).

12. Reiber $\mathrm{H}$, Otto $\mathrm{M}$, Trendelenburg $\mathrm{C}$, Wormek A. Reporting Cerebrospinal Fluid Data: Knowledge Base and Interpretation Software. Clin Chem Lab Med. 2001; 39(4) :324-32.

13. Reiber H. External Quality Assessment in Clinical Neurochemistry: Survey of Analysis for BOS Proteins Based on BOS / serum Quotients, Clin Chem. 1995; 41 (2): 256-63.

14. İrdem A, Ecer S, Özbek MN, Akay H, Devecioğlu C. Subakut Sklerozan Panensefalit Hastalarının Klinik ve Görüntüleme Özellikleri, Dicle Tıp Dergisi. 2004; 31 (1): 48-54.

15. Jacobi C, Lange $P$, Reiber $H$. Quantitation of intrathecal antibodies in cerebrospinal fluid of subacute sclerosing panencephalitis, herpes simplex encephalitis andmultiple sclerosis: discrimination between microorganism-driven and polyspecific immune response. J Neuroimmunol. 2007; 187 (1-2): 139-46.

16. Campbell $\mathrm{H}$, Andrews $\mathrm{N}$, Brown KE, Miller $\mathrm{E}$. Review of the effect of measles vaccination on the epidemiology of the SSPE. Int J Epidemiol. 2007; 36 (6): 1334-48.

17. Ozturk A, Gurses C, Baykan B, Gokyigit A, Eraksoy M. Subacute sclerosing panencephalitis: clinical and magnetic resonance imaging evaluation of 36 patients. J Child Neurol. 2002; 17 (1): 25-9.

18. Ergüven $M$, Fedakar $A$, Saltık $S$, İscan $M$, Usta $M$, Ocal S, et al. Subakut sklerozan panensefalit. Göztepe Tip Dergisi. 2006; 20 (1): 20-2.

19. Honarmand S, Glaser CA, Chow E, Sejvar JJ, Preas $\mathrm{CP}$, Cosentino GC, et al. Subacute sclerosing panencephalitis in the differential diagnosis of encephalitis. Neurology. 2004; 63 (8): 1489-93

20. Şamlığlu P, Ünalp A, Gökçay A, Altuğlu I, Ozturk A, Zeytinoğlu A. Yüksek BOS / serum Kızamık Antikor Indeksi ile Tanımlanan Subakut Sklerozan Panensefalit Olguları. Mikrobiyol Bul. 2012; 46 (4): 716-8. 